\title{
Prevalence of untreated second canal in the mesiobuccal root of maxillary molars and its association with apical periodontitis: A cone beam computed tomography study
}

Prevalência de segundo canal não tratado na raiz mésio vestibular de molares superiores e sua associação com periodontite apical: um estudo em tomografia computadorizada de feixe cônico Prevalencia del segundo canal no tratado en la raíz mesial maxilar de los molares superiores y su asociación con periodontitis apical: un estudio utilizando tomografía computarizada de haz cónico

Key Fabiano Souza Pereira ORCID: https://orcid.org/0000-0001-5403-9283 Federal University of Mato Grosso do Sul, Brazil E-mail: key.pereira@ufms.br

Gustavo dos Santos Lima ORCID: https://orcid.org/0000-0002-0962-2442 Federal University of Mato Grosso do Sul, Brazil

E-mail: sl_gustavo12@hotmail.com

Lia Beatriz Junqueira-Verardo ORCID: https://orcid.org/0000-0001-5989-5679 Federal University of Mato Grosso do Sul, Brazil E-mail: liabeatrizjunqueira@hotmail.com

Alexandre Rodrigues Filho

ORCID: https://orcid.org/0000-0001-6434-3190 Federal University of Mato Grosso do Sul, Brazil

E-mail: branco_filho@ hotmail.com

Hugo Jose Santos Bastos

ORCID: https://orcid.org/0000-0001-9729-4575 Private Dental Practice, Brazil E-mail: hbastus@gmail.com

Vanessa Rodrigues do Nascimento ORCID: https://orcid.org/0000-0002-0579-7501 University of Paraná, Brazil

E-mail: vanessanascimento@prof.unipar.br

Luiz Fernando Tomazinho

ORCID: https://orcid.org/0000-0003-0217-4621 University of Paraná, Brazil

E-mail: tomazinho@prof.unipar.br

\begin{abstract}
This study aimed to evaluate the prevalence of mesiobuccal 2(MB2) canals not located/treated in maxillary molars and correlated their non-treatment with the presence of periradicular lesion. The study was conducted on 180 cone beam computed tomography (CBCT) scans. The 180 examinations added up to 210 teeth analyzed (140 maxillary first molars and 70 maxillary second molars). The presence of non-located/treated MB2 canals and periapical lesions in the mesiobucal(MB) root was identified by observation of the axial and subsequently of sagittal and coronal slices. Among the 210 teeth evaluated, 91.4\% ( $n=192)$ had MB2 canal, while 8.6\% $(n=18)$ did not have this canal. In the first molars with presence of MB2 $(n=133)$, periapical lesion was observed in $85.0 \%(n=113)$. Among the second molars with presence of MB2 $(n=59)$, periapical lesion was observed in $72.9 \%(n=43)$. The presence of periapical lesion in the MB root was related to the non-location/treatment of the MB2 canal and was higher when it was an independent canal.
\end{abstract}

Keywords: Cone beam computed tomography; Periapical periodontitis; Root canal therapy; Endodontics.

\section{Resumo}

Este estudo objetivou avaliar a prevalência de canais mésio-vestibulares 2 (MV2) não localizados / tratados em molares superiores e correlacionar seu não tratamento com a presença de lesão perirradicular. $\mathrm{O}$ estudo foi realizado em 180 tomografias computadorizadas de feixe cônico (TCFC). Os 180 exames totalizaram 210 dentes analisados 
(140 primeiros molares superiores e 70 segundos molares superiores). A presença de canais MB2 não localizados / tratados e lesões periapicais na raiz mésio-vestibular (MV) foi identificada pela observação dos cortes axial e posteriormente dos cortes sagitais e coronais. Dos 210 dentes avaliados, 91,4\% ( $\mathrm{n}=192)$ apresentavam canal MV2, enquanto 8,6\% $(\mathrm{n}=18)$ não possuíam este canal. Nos primeiros molares com presença de MV2 $(\mathrm{n}=133)$, lesão periapical foi observada em 85,0\% $(n=113)$. Entre os segundos molares com presença de MV2 $(n=59)$, lesão periapical foi observada em $72,9 \%(n=43)$. A presença de lesão periapical na raiz MV esteve relacionada à não localização / tratamento do canal MV2 e foi maior quando se tratava de canal independente.

Palavras-chave: Tomografia computadorizada de feixe cônico; Periodontite periapical; Tratamento do canal radicular; Endodontia.

\section{Resumen}

Este estudio tuvo como objetivo evaluar la prevalencia de canales mesiobucales 2 (MB2) no localizados / tratados en molares superiores y correlacionó su no tratamiento con la presencia de lesión perirradicular. El estudio se realizó en 180 tomografías computarizadas de haz cónico (CBCT). Los 180 exámenes sumaron 210 dientes analizados (140 primeros molares superiores y 70 segundos molares superiores). La presencia de canales MB2 no localizados / tratados y lesiones periapicales en la raíz mesiobucal (MB) se identificó mediante la observación de cortes axiales y posteriormente sagitales y coronales. Entre los 210 dientes evaluados, el 91,4\% ( $\mathrm{n}=192)$ tenía canal MB2, mientras que el 8,6\% ( $\mathrm{n}=18)$ no tenía este canal. En los primeros molares con presencia de MB2 $(\mathrm{n}=133)$ se observó lesión periapical en 85,0\% $(n=113)$. Entre los segundos molares con presencia de MB2 $(n=59)$, se observó lesión periapical en el $72,9 \%(n=43)$. La presencia de lesión periapical en la raíz de MB se relacionó con la no localización / tratamiento del canal MB2 y fue mayor cuando se trataba de un canal independiente.

Palabras clave: Tomografía computarizada de haz cónico; Periodontitis periapical; Tratamiento del conducto radicular; Endodoncia.

\section{Introduction}

Providing comfort, function, longevity and esthetics is the main goal of endodontic treatment for patients affected by oral diseases or traumatic injuries. The success in these goals is achieved by significant reduction of microorganisms in the root canal system (RCS), or by prevention of contamination or recontamination (Nair, 2004).

The failure of endodontic therapy is usually indicated by the presence of signs and symptoms persisting after treatment. Conversely, the absence of clinical symptoms does not necessarily indicate a positive treatment outcome (Torabinejad et al., 2018). There may be periapical pathologies without significant clinical symptoms before or after treatment (Lin et al., 1991).

Many studies investigated the prevalence of periradicular lesion and the factors leading to its appearance. Most of these factors are related to technical problems as failures in the working length adopted, root canal shaping and disinfection and the quality of obturation and coronal restoration (Costa et al., 2019). However, the most common cause of indication for reintervention is the presence of an untreated canal, due to failure in its location (Karabucak et al., 2016).

Some dental groups are known to present canals that are difficult to locate, including the maxillary molars (Alaçam et al., 2008). These teeth usually have 3 roots and high prevalence of 4 canals, with this extra canal (MB2) located in the mesiobuccal root, which is difficult to identify on the pulp chamber floor and turned toward palatal aspect of the root. In the scientific literature, the prevalence of MB2 exceeds $80 \%$, being more common in the cervical than in the middle and apical thirds, in first and second maxillary molars presenting 3 roots (Reis et al., 2013). Even though the science has documented the prevalence of MB2 canals in maxillary molars, an important anatomical data yet to be elucidated concerns the presence of an independent apical foramen in the MB2 canal, since in these cases, if it is not located and treated, due to this direct communication with periradicular tissues, it can lead to treatment failure (Alaçam et al., 2008).

In the last 10 years, the use of digital imaging has become routine in the dental clinic. The cone beam computed tomography (CBCT), introduced during the 1990s, provides detailed information in three-dimensional imaging (Patel e al., 2019). Currently, CBCT has substantially improved the quality of images, by high-resolution scanners or specific softwares that presents for this navigational tools and adequate filters (Bueno e al., 2018). 
Knowing that if a canal is not detected in endodontic treatment, this might be a potential cause of failure, the aim of this study was to identify the prevalence of MB2 canals not located/treated in first and second maxillary molars with endodontic treatment and correlated its non-treatment to the presence of periapical lesion.

\section{Methodology}

This study was approved by the Institutional Review Board of the Federal University of Mato Grosso do Sul (UFMS), under protocol n. CAAE: 1529319600000021.

A total of 250 tomographies of Brazilian individuals were selected from the database of a private Oral Radiology clinic in Campo Grande - MS, including examinations performed in the years 2018 to September 2019. The scans were acquired with PREXION 3D (Yoshida Dental Mfg Co Ltd, Inc. - JAPAN). The following parameters were set: 90kV, 4mA, voxel size $0.1 \mathrm{~mm}$, focal spot size $0.3 \times 0.3 \mathrm{~mm}, 0.09 \mathrm{~mm}$ cutting thickness and FOV 50x50mm. The DICOM export software was HOROS (Horos Project, USA).

The tomographic images were initially analyzed to screen cases presenting first and second molars with previous endodontic treatment. The image contrast, brightness and size (zoom) were changed when needed, using the software, to assure the ideal visualization.

Subsequently, two endodontists, experienced in analyzing CBCT scans, independently evaluated the images of these teeth, and in case of discordance a third examiner was included for resolution. The examiners were calibrated by examining 50 initial CBCT scans.

The images of the axial, sagittal and coronal planes of each root of the afore mentioned teeth were aligned vertically and horizontally making parallel lines along the long axis of each canal. The variables (presence of MB2 canal not located/treated, separate MB1 and MB2 canals and presence of periapical lesion in the MB root) were investigated in the visualization of axial slices and subsequently in sagittal and coronal slices, to confirm the finding (Figures 1,2). Untreated canals appearing from the cementoenamel junction to the apex, including canals dividing from the main canal in the cervical, middle or apical thirds, were considered as non-located/treated canals. The presence of periradicular lesion was confirmed when there was rupture of the lamina dura, with presence of a low-density area associated with the apex, with at least twice the thickness of the normal periodontal ligament space. The records found were inserted in a spreadsheet for later statistical analysis.

From the $250 \mathrm{CBCT}$ analyzed, 70 were excluded due to poor image quality or many artifacts from metallic retainers or screws and mini-implants close to the apical region of the MB root, endodontic-periodontal lesions in which it was not possible to identify the origin of the periapical lesion; teeth with treated MB2; poorly positioned examinations, in which the apex did not appear on the image; canals fully calcified throughout the length of the MB root; strip perforations, apical resorption, apicectomized teeth and roots fused in the apical region containing large periapical lesions.

The 180 CBCTs included 210 teeth analyzed (140 upper first molars and 70 upper second molars). The association between the molar tooth (first or second) and the other variables evaluated in this study (presence of MB2 canal, presence of separate canals in teeth with MB2, presence of periapical lesion in the MB root in teeth with MB2, and periapical lesion in the MB root of teeth with MB2 and separate canals) was evaluated by the chi-square test. The other results of this study were presented by descriptive statistics or as table and graph. Statistical analysis was performed using the SPSS statistical software, version 24.0, considering a significance level of $5 \%$. 
Research, Society and Development, v. 10, n. 2, e55410212906, 2021

(CC BY 4.0) | ISSN 2525-3409 | DOI: http://dx.doi.org/10.33448/rsd-v10i2.12906

Figure 1. Note in " $A$ " the three planes from left to right (coronal, axial and sagittal) evidencing the periapical lesion and presence of MB2 canal. The image in "B" confirms the independent MB2 canal on the coronal and axial sections. In another tooth, in " $\mathrm{C}$ " and " $\mathrm{D}$ ", the MB2 canal is observed on the axial section and confirmed on the sagittal section, also evidencing independent canals.
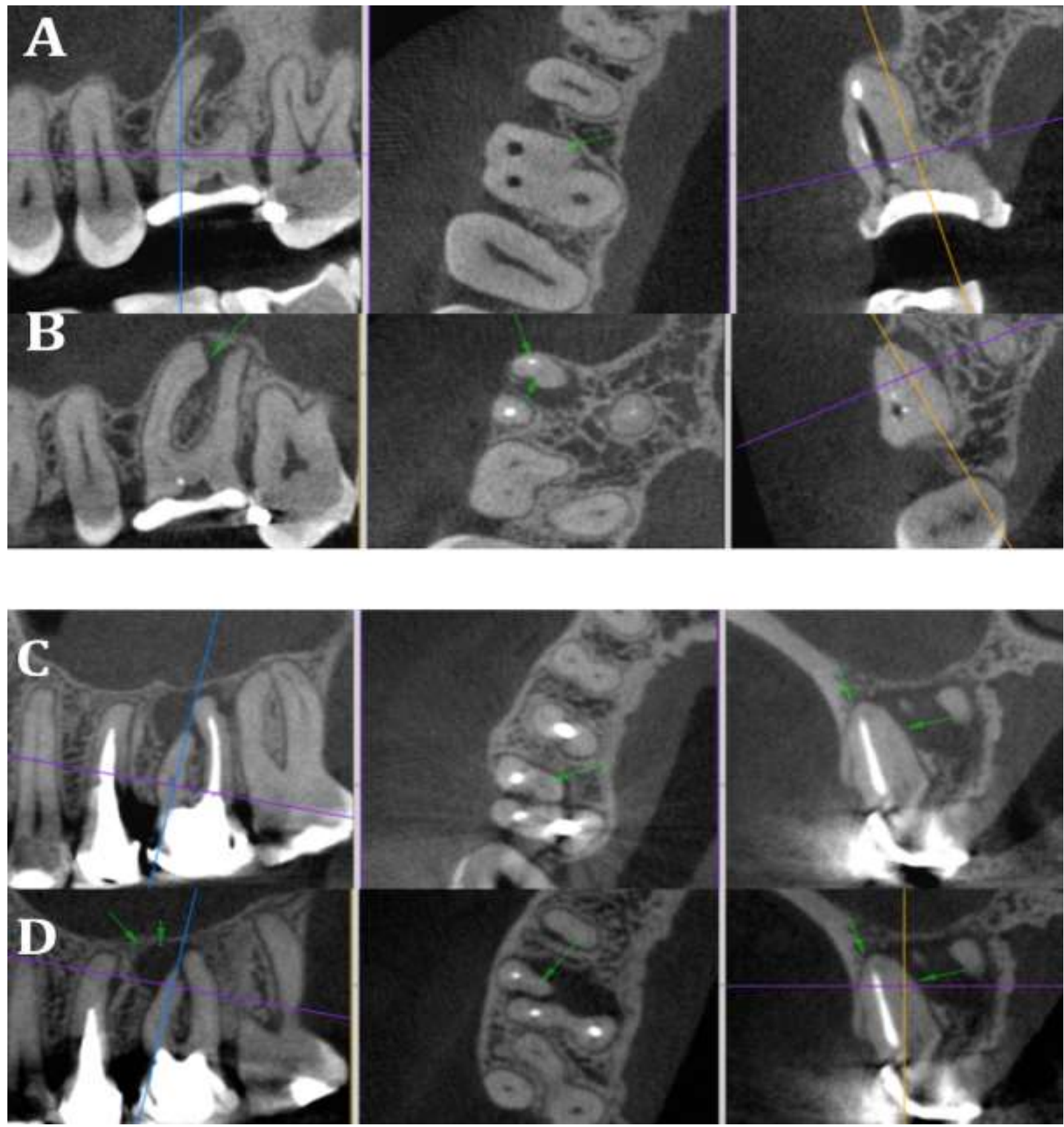

Source: Authors. 
Research, Society and Development, v. 10, n. 2, e55410212906, 2021

(CC BY 4.0) | ISSN 2525-3409 | DOI: http://dx.doi.org/10.33448/rsd-v10i2.12906

Figure 2. Observe the presence of MB2 canal on the axial section. On the sagittal section, the arrows indicate the periapical lesion and the root canals ending in a single foramen. The apical limit of instrumentation and unsatisfactory obturation of the MB1 canal may also be observed.
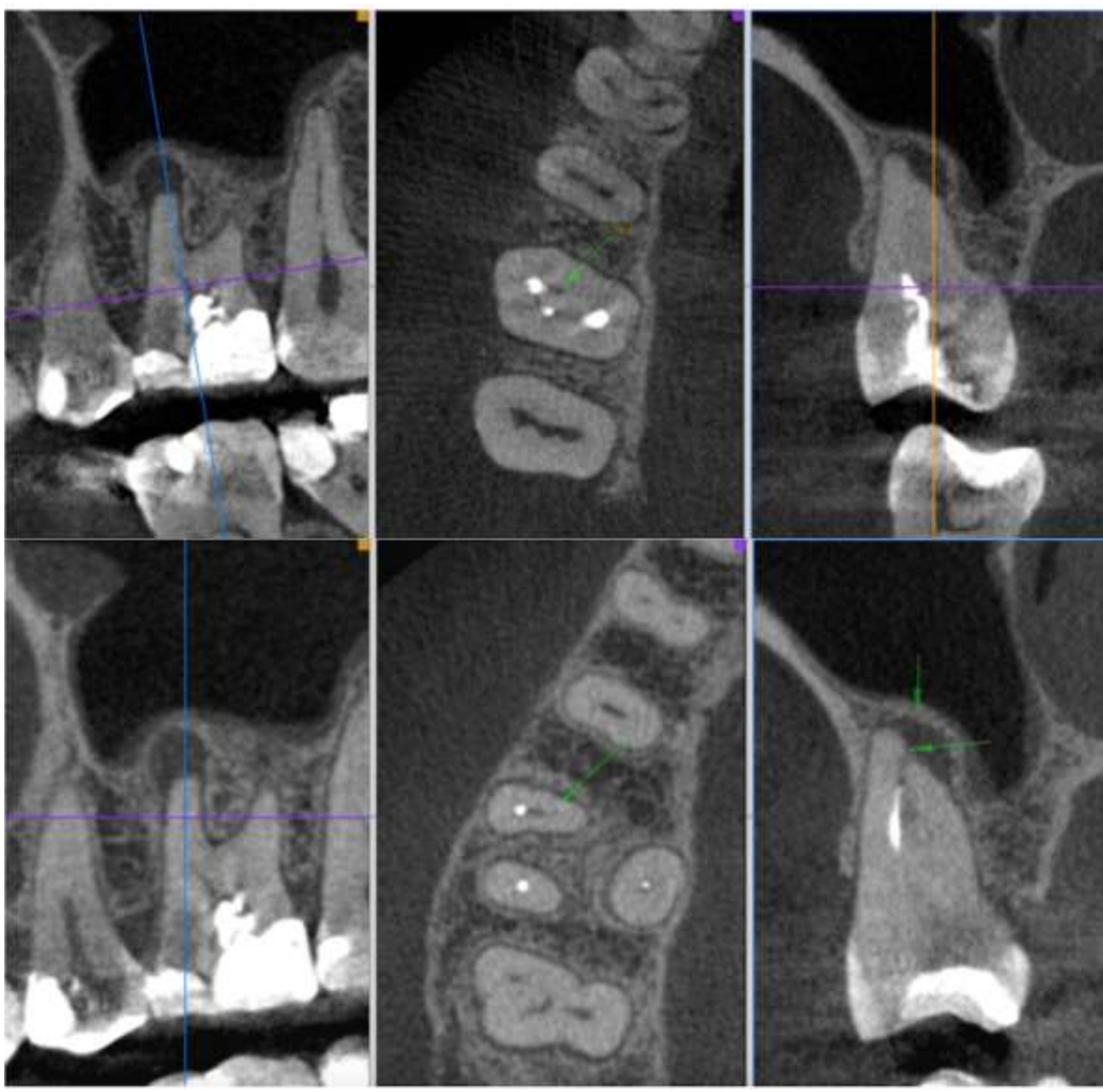

Source: Authors.

\section{Results}

Among the 210 teeth evaluated in this study, 91.4\% ( $\mathrm{n}=192)$ had an MB2 canal, while 8.6\% ( $\mathrm{n}=18)$ did not have this canal.

Among teeth with MB2 canal ( $\mathrm{n}=192), 9.4 \%(\mathrm{n}=18)$ did not have separate canals, 77.6\% had separate canal and in $13.0 \%(n=25)$ it was impossible to identify the presence of a separate canal.

Also, among those who had an MB2 canal ( $\mathrm{n}=192), 81.3 \%(\mathrm{n}=156)$ had a periapical lesion in the MB root.

Among the teeth with the presence of MB2 canal and presenting a separate canal ( $\mathrm{n}=149), 87.9 \%(\mathrm{n}=131)$ had a periapical lesion in the MB root.

Among the 140 maxillary first molars (1MM) evaluated in this study, 95.0\% (n=133) had MB2 canal. Among the 70 maxillary second molars $(2 \mathrm{MM})$ evaluated, $84.3 \%(\mathrm{n}=59)$ had MB2 canal. The percentage of 1MM with MB2 canal was 
significantly higher than observed for 2MM (chi-square test, $\mathrm{p}=0.009$ ).

Among the $1 \mathrm{MM}$ that had MB2 canal $(\mathrm{n}=133), 78.2 \%$ of them $(\mathrm{n}=104)$ had separate canals. Among the $2 \mathrm{MM}$ that had MB2 ( $=59), 76.3 \%$ of them had a separate canal. There was no significant association between the molar tooth with MB2 and the presence of a separate canal (chi-square test, $\mathrm{p}=0.440$ ).

Among 1MM with presence of MB2 ( $\mathrm{n}=133)$, periapical lesion was observed in $85.0 \%(\mathrm{n}=113)$. Among the $2 \mathrm{MM}$ with presence of MB2 ( $n=59)$, periapical lesion was observed in $72.9 \%(n=43)$. The percentage of 1 MM with presence of MB2 canal that had a periapical lesion in the MB root was significantly higher than observed for 2MM, also with presence of MB2 (chi-square test, $\mathrm{p}=0.048$ ).

Finally, among the 1MM that had MB2 canals and a separate canal $(n=104), 90.4 \%(n=94)$ had a periapical lesion in the MB root. Among the 2MM that also had MB2 canals and a separate canal $(n=45), 82.2 \%(n=37)$ had a periapical lesion in the MB. There was no significant difference between 1MS and 2MS that had MB2 canals and a separate canal in relation to the percentage of periapical lesion in the MB root (chi-square test, $\mathrm{p}=0.259$ ). These results were summarized as see in the Table 1 .

Table 1. Results of comparison between first and second molars, concerning the presence of MB2 canals, separate canal and periapical lesion on the MB root, as well as overall evaluation of all teeth analyzed in this study.

\begin{tabular}{|c|c|c|c|c|}
\hline Variable & $\begin{array}{l}\text { Total } \\
\%(n)\end{array}$ & $\begin{array}{c}1^{\text {st }} \text { molar } \\
\%(n)\end{array}$ & $\begin{array}{c}2^{\text {nd }} \text { molar } \\
\%(n)\end{array}$ & p value \\
\hline MB2 canal & $(n=210)$ & $(n=140)$ & $(n=70)$ & \\
\hline No & $8.6(18)$ & $5.0(7)$ & $15.7(11)$ & 0.009 \\
\hline Yes & 91.4 (192) & $95.0(133) \mathrm{a}$ & 84.3 (59)b & \\
\hline $\begin{array}{l}\text { Separate canals in teeth } \\
\text { with MB2 }\end{array}$ & $(n=192)$ & $(n=133)$ & $(n=59)$ & \\
\hline No & 9.4 (18) & $10.5(14)$ & $6.8(4)$ & 0.440 \\
\hline Yes & 77.6 (149) & $78.2(104) \mathrm{a}$ & $76.3(45) \mathrm{a}$ & \\
\hline $\begin{array}{l}\text { Cannot be } \\
\text { identified }\end{array}$ & $13.0(25)$ & $11.3(15)$ & $16.9(10)$ & \\
\hline $\begin{array}{l}\text { Periapical lesion on the } \\
\text { MB root (teeth with } \\
\text { MB2) }\end{array}$ & $(n=192)$ & $(n=133)$ & $(n=59)$ & \\
\hline No & $18.8(36)$ & $15.0(20)$ & $27.1(16)$ & 0.048 \\
\hline Yes & 81.3 (156) & $85.0(113) \mathrm{a}$ & $72.9(43) \mathrm{b}$ & \\
\hline $\begin{array}{l}\text { Periapical lesion on the } \\
\text { MB root (teeth with } \\
\text { MB2 and separate }\end{array}$ & $(n=149)$ & $(n=104)$ & $(n=45)$ & \\
\hline No & $12.1(18)$ & $9.6(10)$ & $17.8(8)$ & 0.259 \\
\hline Yes & 87.9 (131) & $90.4(94) \mathrm{a}$ & $82.2(37) \mathrm{a}$ & \\
\hline
\end{tabular}


$\mathrm{P}$ value on the chi-square test. Different letters in the line indicate significant difference between the first and second molars $(\mathrm{p}<0.05)$ Source: Authors

The results of the difference between $1 \mathrm{MM}$ and $2 \mathrm{MM}$ in relation to the presence of $\mathrm{MB} 2$ canal and periapical lesion in the MB root in teeth with presence of MB2 canal are shown in Graph 1.

Graph 1. Presenting the percentage of first and second molars concerning the presence of MB2 canal and periapical lesion on the MB root of teeth with presence of MB2 canal.

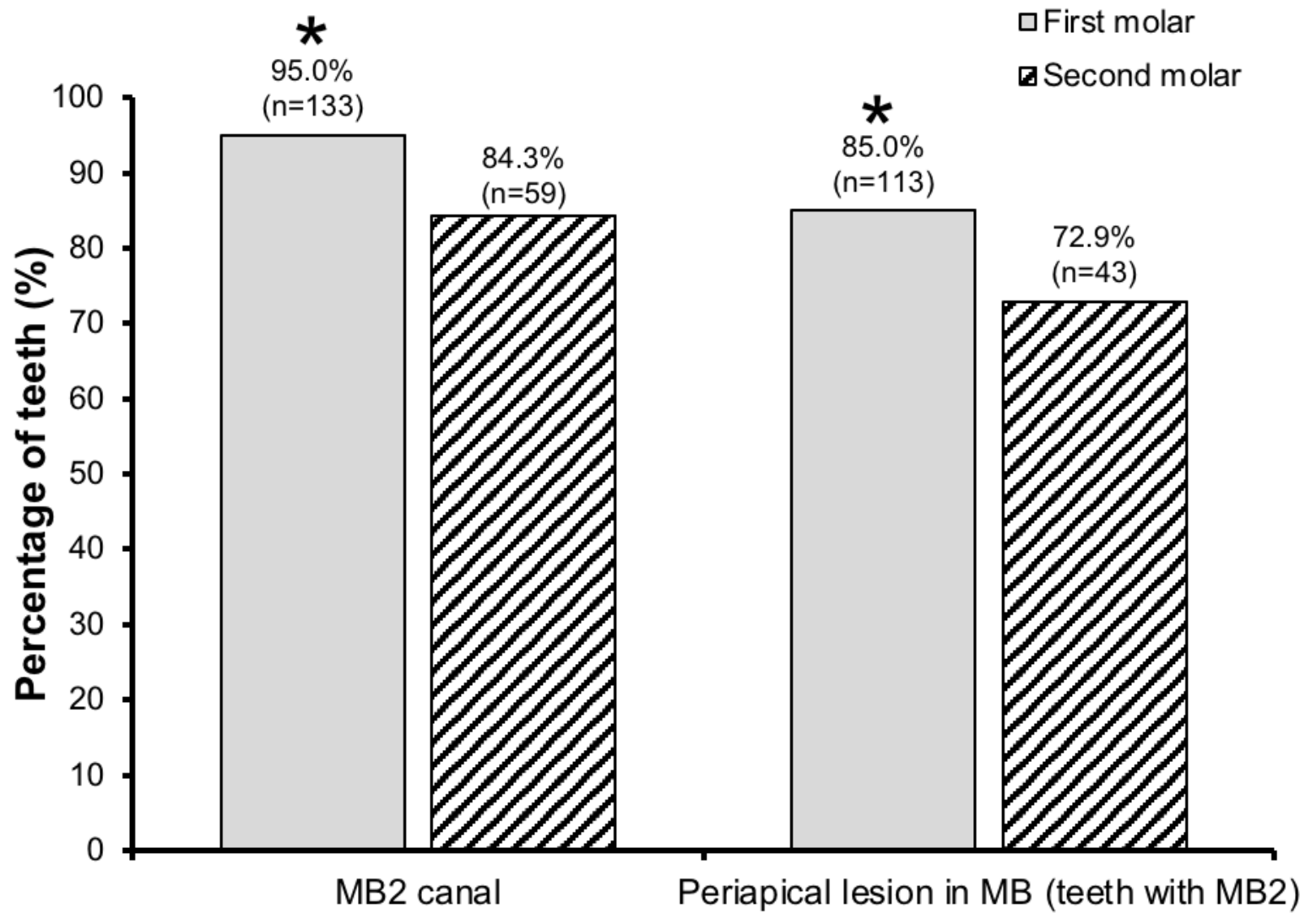

Each column represents the percentage value. * Significant difference in relation to second molars (chi-square test, MB2 canal: $\mathrm{p}=0.009$; Periapical lesion on MB in teeth with MB2: $\mathrm{p}=0.048$ ).

Source: Authors.

\section{Discussion}

Science has long acknowledged the anatomical complexity inherent to maxillary molars, because of the presence of 2 canals in the MB root (Weine et al., 1969). Currently, with the advent of better techniques to investigate the internal dental anatomy, the identification of maxillary molars with two canals in the MB root increased dramatically (Filho et al., 2009; Martins et al., 2018). Thus, the anatomical characteristic of these teeth, namely an extra canal in the MB root, the MB2, has become more a rule than an exception.

The present results regarding the prevalence of MB2 were high, in agreement with the most recent investigations that also used CBCT for this assessment (Hiebert et al., 2017; Zhang et al., 2017). Due to the presence of MB2, maxillary molars are the teeth with the largest number of canals not found and periapical lesions, when compared to other dental groups (Costa et al., 2019; Baruwa et al., 2020). 
Another important data observed was, in the presence of MB2, if it had a different apical path than MB1, i.e. if there was an independent foramen. More than 2/3 of analyzed teeth presented MB2 canal with independent foraminal exit and, among these, the presence of periapical lesion was observed in $87.9 \%$. This information is relevant and supports the statement that canals that are not located/treated and have direct contact with the periodontium can lead to treatment failure (Alaçam et al., 2008). Important studies, which yet did not assess the separation of MB1 and MB2 canals, also reported high rate of periapical lesions due to non-location/treatment of the MB2 canal (Costa et al., 2019; Karabucak et al., 2016; Baruwa et al., 2020).

It was also analyzed whether there was higher prevalence of MB2 between 1MM and 2MM. The MB2 canal was more present in $1 \mathrm{MM}(95 \%)$ than in 2MM (84.3\%), corroborating a recent study that also employed CBCT (Fernandes et al., 2018). However, there was no difference when the separation of these canals was analyzed between the two types of teeth. Following the analyzed data, comparing the presence of periapical lesion, in general, 1MM exhibited more lesions in the MB root compared to $2 \mathrm{MM}$, but when the analysis was performed only between MB roots that had two separate canals, the two maxillary molars did not differ concerning the presence of lesion. The similarity of the presence of periapical lesion in molars with separate MB1 and MB2 is strongly assigned to the fact that an untreated canal can harbor a primary bacterial infection or act as a secondary infection site in the root canal system. Once infected and depending on the bacterial load, virulence and access to periradicular tissues, infection in the untreated canal can cause or maintain the apical periodontitis (Costa et al., 2019; Ricucci et al., 2010; Nair. 2006).

In 25 teeth, it was not possible to safely state the separation or not of canals in the apical third. The age of patients may have contributed to such limitation, since the older the age, the more difficult to find MB2 canals, or when they exist, they are not found in the middle and apical thirds due to dentin apposition on the root canal walls (Reis et al., 2013).

Strategies for locating the MB2 canal in maxillary molars are extensively investigated and, among them, the use of magnification is fundamental (Buhrley et al., 2002). The combined use of surgical microscope and ultrasonic tips to perform selective wear on the mesial wall and pulp chamber floor detected significantly more MB2 canals than when no magnification was used on maxillary first molars (Alaçam et al., 2008). Even though these new technologies increase the percentage of location of the MB2 canal, many treatments are performed, and this canal is not found due to the level of experience of dental professionals. Corcoran et al., (2007), showed that the operator's experience directly influences the ability of location and biomechanical preparation of MB2 canals.

CBCT is another highly effective resource to assist the location of the MB2 canal (Costa et al., 2019; Filho et al., 2009; Hiebert et al., 2017; Baruwa et al., 2020; Fernandes et al., 2018). When the MB2 canal was not clinically found, the CBCT was used and the location rates increased considerably (Hiebert et al., 2017). According to Karabucak et al., (2016), CBCT with small FOV (better resolution) should be examined before any endodontic re-intervention to identify nonlocated/treated canals.

Some authors emphasize that, even though CBCT is excellent in identifying the canals, it is not adequate to expose the patient to this examination before primary endodontic treatments (Hiebert et al., 2017). Conversely, Filho et al., (2009), based on the good results achieved in locating the MB2 canal using a microscope and tomography, suggest previous CBCT to identify the complex anatomy of the $1 \mathrm{MM}$ and consequent success in locating additional canals as the MB2. Even though the most recent statement of the European Society of Endodontics (Patel et al., 2019), does not clearly indicate CBCT prior to endodontic treatment.

Considering the results found in this study, we understand that CBCT should be requested before any endodontic treatment of maxillary molars. Furthermore, future research is suggested to investigate more indications to use of CBCT in 
order to improve the quality and results of root canal treatment. After achievement of the present data, it is clear that the endodontic treatment of maxillary molars requires greater attention in the teaching/learning process concerning the awareness on its complex anatomy, especially the high prevalence of MB2 canals, as well as the need to highlight the importance of using technologies, as described above, that combined with good and constant training may increase the endodontic treatment to higher success levels.

\section{Conclusion}

There was high prevalence of MB2 canals non-located/treated. The presence of periapical lesion in the MB root was related to non-location/treatment of the MB2 canal and was higher when it was an independent canal.

\section{References}

Alaçam, T., Tinaz, A., Genç, O., \& Kayaoglu, G. (2008). Second mesiobuccal canal detection in maxillary first molars using microscopy and ultrasonics. Aust Endod J, 34, 106-9.

Baruwa, A. O., Martins, J. N. R., Meirinhos, J., et al. (2020). The Influence of Missed Canals on the Prevalence of Periapical Lesions in Endodontically Treated Teeth: A Cross-sectional Study. J Endod, 46, 34-39.

Bueno, M. R., Estrela, C., Azevedo B. C., \& Diógenes, A. (2018). Development of a New Cone-Beam Computed Tomography Software for Endodontic Diagnosis. Braz D J, 29, 517-29

Buhrley, L. J., Barrows, M. J., BeGole, E. A., \& Wenckus, C. S. (2002). Effect of magnification on locating the mb2 canal in maxillary molars. J Endod, 28, 324-27.

Corcoran, J, Apicella, M. J., \& Mines, P. (2007). The effect of operator experience in locating additional canals in maxillary molars. J Endod, $33,15-17$.

Costa, F. J., Pacheco-Yanes, J., Siqueira, J. F. Jr., et al. (2019). Association between missed canals and apical periodontitis. Int Endod J, 52, $400-6$.

Fernandes, N. A., Herbst, D., Postma, T. C., \& Bunn, B. K. (2018). The prevalence of second canals in the mesiobuccal root of maxillary molars: A cone beam computed tomography study. Aust Endod J, 45, 46-50.

Filho, F. B., Zaitter, S., Haragushiku, G. A., Campos, E. A., Abuabara, A. \& Correr, G. M. (2009). Analysis of the internal anatomy of maxillary first molars by using different methods. J Endod, 35, 337-42.

Hiebert, B. M., Abramovitch, K., Rice, D., \& Torabinejad, M. (2017). Prevalence of second mesiobuccal canals in maxillary first molars detected using conebeam computed tomography, direct occlusal access, and coronal plane grinding. J Endod, 43, 1711-15.

Karabucak, B., Alf Bunes, D. M., Chehoud, A. B., Meetu, R. K., \& Frank, S. (2016). Prevalence of apical periodontitis in endodontically treated premolars and molars with untreated canal: a cone-beam computed tomography study. J Endod, 42, 538-41.

Lin, L. M., Pascon, E. A., Skribner, J., Gangler, P., \& Langeland, K. (1991). Clinical, radiographic, and histologic study of endodontic treatment failures. Oral Surg Oral Med Oral Pathol, 71, 603-11.

Martins, J. N. R., Alkhawas, M. B., Altaki, Z., et al. (2018). Worldwide analyses of maxillary first molar second mesiobuccal prevalence: a multicenter conebeam computed tomographic study. J Endod, 44, 1641- 49.

Nair, P. N. (2004). Patoghenesis of apical periodontitis and the causes of endodontic failures. Crit Rev Oral Biol Med, 15, 348-81.

Nair, P. N. (2006). On the causes of persistent apical periodontitis: a review. Int Endod J, 39, 249-81.

Patel, S., Brown, J., Semper, M., Abella, F., \& Mannocci, F. (2019). European Society of Endodontology position statement: Use of cone beam computed tomography in Endodontics. Int Endod J, 52, 1675-78.

Reis, A. G., Grazziotin-Soares, R., Barletta, F., Fontanella, V. R., \& Mahl, C. R. (2013). Second canal in mesiobuccal root of maxillary molars is correlated with root third and patient age: a cone-beam computed tomography study. J Endod, 39, 588-92.

Ricucci, F., \& Siqueira, J. F. Jr. (2010). Biofilms and apical periodontitis: study of prevalence and association with clinical and histopathologic findings. $J$ Endod, 36, 1277- 88.

Torabinejad, M., Rice, D., Maktabi, O., Oyoyo, U., \& Abramovitch, K. (2018). Prevalence and size of periapical radiolucencies using cone-beam computed tomography in teeth without apparent intraoral radiographic lesions: a new periapical index with a clinical recommendation. $J$ Endod, $44,389-94$.

Weine, F. S., \& Healey, H. J. (1969). Canal configuration in the mesiobuccal root of the maxillary first molar and its endodontic significance. Oral Surg Oral Med Oral Pathol, 28, 419-25. 
Research, Society and Development, v. 10, n. 2, e55410212906, 2021 (CC BY 4.0) | ISSN 2525-3409 | DOI: http://dx.doi.org/10.33448/rsd-v10i2.12906

Zhang, Y., Xu, H., Wang, D., et al. (2017). Assessment of the second mesiobuccal root canal in maxillary first molars: a cone-beam computed tomographic study. J Endod, 43, 1990-96. 